\title{
Editorial
}

\section{Accountability at law of regulatory decisions}

The closure of the Bank of Credit and Commerce International (BCCI) in 1991 led to a flood of litigation with the action against the Bank of England (the Bank), in its capacity as regulator of banks in the UK, being the most prominent and controversial. The contentious case against the Bank finally began on 13th January, 2004, with its reputation coming under intense fire from $\mathrm{Mr}$ Gordon Pollock QC, acting for the depositors. The closure of BCCI was based on the fact that the bank had perpetrated one of the most shocking financial frauds of modern times - linked with both terrorist finance and money laundering. The plaintiffs allege that the loss to depositors resulted from the Bank's failure to carry out its responsibilities under the Banking Act 1987, and that the failure enabled BCCI to accrue losses of billions of pounds through its fraudulent activities around the world (Three Rivers DC $v$ Governor \& Company of the Bank of England [2000] HL 3 All ER 1, and Three Rivers DC $v$ Governor \& Company of the Bank of England [2001] HL 2 All ER 513). The case will shed considerable light on the sensitive and difficult decisions surrounding financial regulation and supervision. It will also bring to the fore the limits of supervision to control the affairs of autonomous entities.

In the Three Rivers actions, the plaintiffs seek damages from the Bank in misfeasance in public office rather than an action in the tort of negligence - from which the Bank has an express immunity. This immunity from liability emanates from two sources: case law (Yeun Kun Yeu v Attorney General of Hong Kong [1987] 2 All ER 705; Johnson Matthey Plc v Arthur Young and The Governor of the Bank of England [1989] 2 All ER 105; and Davis v Percy Radcliffe [1990] 1 WLR 821); and s. 1(4) of the Banking Act 1987. The underlying policy concern for the express immunity has in many respects followed the implied immunity advocated by the courts, which is to allow the regulator to execute their responsibilities without facing a dark cloud of liability for their decisions. The responsibilities conferred on a public body are normally couched in broad normative terms that require it to exercise discretion within the confines of its statutory remit. This would be executed in the public interest or for public purposes and not in the interest of individual members of the public. Public bodies undertake their responsibilities with scarce resources available to achieve their policy objectives; however, that does not mean safety measures can be circumvented. The imposition of a legal responsibility on the public body in such circumstances could lead to resources being given to an area simply to avoid litigation. It is also suggested that the threat of litigation could lead to further layers of regulation as an avoidance mechanism, which could result in higher compliance costs for the industry.

More importantly, in circumstances of financial failure, regulation does not attempt to eliminate all risk to the consumer - caveat emptor does apply. It is invariably the case that the loss caused by financial insolvency may not be solely 
attributable to the public body but may in these circumstances be a failure of the regulated entity where the regulator acts as a third party in the interests of the consumer. Therefore statutory immunity needs to be balanced against legitimate claims for compensation for the loss that ensues from financial insolvency. This objective is achieved, to a limited extent, by insurance schemes within statutes that govern financial regulation. Consequently, in a number of instances, individuals may have had their loss covered by deposit insurance schemes so they would not need to seek further compensation through the courts.

The tort of misfeasance in public office has a very long history with its roots dating back centuries where some of the early decisions overlapped with actions relating to deceit. ${ }^{1}$ The tort of misfeasance in public office is confined to acts or omissions of a public officer who serves the public interest. These responsibilities of a public officer need to be exercised in good faith and without conflict. Therefore, individuals responsible for banking supervision, in accordance with the Banking Act 1987, would be construed to be in a position of public office. The scope of misfeasance in public office is not confined to unlawful administrative acts because it includes elements of misuse of power and not just the invalidity of an act or an omission. This distinguishes actions in the tort of misfeasance from actions that constitute a tort of negligence and breach of statutory duty against public authorities. Therefore, the tort cannot even be equated with gross negligence because in an action in misfeasance in public office the subjective state of mind needs to be considered.

Abuse of office is at the heart of misfeasance in public office, which can manifest itself as a disregard of whether the act or omission is dishonest, which in some instances is analogous with 'gross abuse of legal power'. The abuse of public office is represented in two alternative ways: where the public officer's act or omission is underpinned by malice with the intention of causing injury, or where the public officer has knowledge that the act or omission is unlawful. The latter is construed to mean that the public officer has knowledge that the act or omission was beyond his power and that it would probably cause injury to the claimant; or alternatively was reckless by wilfully disregarding a risk of injury to the claimant which he knew was unlawful. This part of the second limb of the tort is equivalent to a public officer 'turning a blind eye' to what is going on and flagrantly disregarding the consequences of the injury that may ensue.

The allegations point to the failures of specific bank officials rather than the Bank per se, citing among them three former bank governors who are claimed to have acted in bad faith. It is alleged inter alia that they licensed BCCI in 1979 when they knew that it was unlawful to do so, 'shut their eyes' to what was happening at BCCI after the licence was granted, and failed to close BCCI despite the information available. The cause of action also includes inter alia other pertinent issues: the plaintiffs allege that the Bank had placed too much reliance on the powers of s. 3(5) of the Banking Act 1979, and later s. 9(3) of the Banking Act 1987, and upon assurance from the Luxembourg Banking Commission (LBC) and the Institut Monétaire Luxembourgeois (IML) that the management and financial status of BCCI were both sound. They allege that the Bank was not entitled to rely on assurance given by the LBC and the IML because, in its own opinion, those institutions were not competent to give assurance about BCCI's management or financial soundness. The Bank itself was dissatisfied with the supervision of BCCI's activities by the LBC and the IML. It nevertheless permitted BCCI to carry on its business from 100 Leadenhall Street, London. 
The chronological evidence provided by the Bingham Report ${ }^{2}$ into the whole closure shows the complexity of the case. Lord Hobhouse estimated that the trial would last for a year at least and, being a case without real prospect of success, it would use a disproportionate amount of resources and court time. The Lords were at pains to make clear that the question of whether the case should be struck out does not necessarily mean that the allegations are not proven. Therefore, on this basis, it was accepted that the claim should proceed on a purely objective basis and without any pre-conditions regarding the outcome of the case. This decision was made after consideration of the numerous issues raised by the Bingham Report. For Lord Hope the complexity of many of the allegations warranted the decision not to simply strike out the whole claim.

The punitive nature of misfeasance in public office places it at the most severe end of the civil liability spectrum. Therefore, the evidentiary burden of proof to be discharged will need to be set at a level which more than satisfies the seriousness of the claim to protect the integrity of those implicated. This is particularly the case if they are to establish that it was dishonesty in the way the BCCI was regulated and supervised that led to the ensuing losses that it accrued.

\section{RefERENCES}

(1) Evans, R. C. (1982) 'Damages for unlawful administrative action: The remedy for misfeasance in public office', International and Comparative Law Quarterly, Vol. 31, pp. 640-660.

(2) 'Inquiry into the Supervision of the Bank of Credit and Commerce International by the Right Honourable Lord Bingham' (1992) HMSO, London.

Dalvinder Singh

Lecturer in Law

Oxford Brookes University

IALS Editor

February 2004 